\title{
Efektifitas Problem Based Learning Dengan Pendekatan Saintifik Untuk Meningkatkan Kemampuan Keterampilan Berfikir Kritis Mahasiswa
}

\author{
Adi Candra Kusuma ${ }^{1}$, Dwi Setia Mujiono ${ }^{2}$ \\ ${ }^{1}$ Politeknik Harapan Bersama \\ Email: candraraden45@gmail.com \\ ${ }^{2}$ Politeknik Harapan Bersama \\ Email: dwichoshy@gmail.com
}

\begin{tabular}{l}
\hline \multicolumn{1}{c}{ Journal info } \\
\hline Jurnal Pendidikan Glasser \\
p-ISSN : 2579-5082 \\
e-ISSN : $2598-2818$ \\
DOI :
\end{tabular}

10.32529/glasser.v\%vi\%i.332

Volume : 3

Nomor : 2

Month : 2019

Issue : oktober

\begin{abstract}
.
Berbagai kendala dalam proses pembelajaran matematika telah dialami oleh mahasiswa dan dosen sendiri dalam proses pembelajaran di kelas sehingga membutuhkan metode pembelajaran yang cocok digunakan. Tujuan dari penelitian yang dilakukan adalah diperolehnya efektifitas pembelajaran $P B L$ dengan pendekatan saintifik untuk meningkatkan kemampuan Keterampilan berfikir kritismahasiswa. Dengan metode yang digunakan eksperimen (kuantitatif) yang telah diskemakan dengan mengambil subjek penelitian mahasiswa Prodi Teknik Komputer semester II kelas D sebagai kelas kontrol dan kelas F sebagai kelas eksperimen pada Tahun Akademik 2018/2019 pada bahasan Statistika. Metode pengumpulan data menggunakan observasi, wawancara, tes soal seperti validitas, reliabelitas, daya beda dan tingkat kesukaran soal. Hasil penelitian sebagai berikut (1) ketuntasan individu memenuhi KKM (68), (2) ketuntasan klasikal sebesar $75 \%$ dengan proporsi mahasiswa sudah mendapatkan nilai 68 sudah melampaui 75\%; (3) kemampuan Keterampilan berfikir kritismahasiswa pembelajaran $P B L$ dengan pendekatan saintifik sebesar 79,5 lebih tinggi dari pembelajaran ekspositori sebesar 76,2 (4) adanya peningkatan kemampuan Keterampilan berfikir kritismahasiswa sebesar 0.464 kategori sedang kemudian selisih peningkatan kemampuan Keterampilan berfikir kritis mahasiswa yang diberikan perlakuan pembelajaran $P B L$ dengan pendekatan saintifik lebih besar dari pembelajaran Ekspositori.
\end{abstract}

Keywords: PBL, Pendekatan Saintifik, Kemampuan Keterampilan berfikir kritis

\section{A. PENDAHULUAN}

Perkembangan ilmu pengetahuan abad

21 menuntut individu untuk menjadi sumber daya manusia (SDM) yang berkualitas. Ciriciri SDM yang berkualitas adalah mampu mengelola menggunakan dan mengembangkan keterampilan berpikir. Melihat adanya persaingan tersebut
Perguruan Tinggi dituntut untuk selalu meningkatkan kualitas lulusan sehingga para lulusan mampu bersaing di dunia kerja. Untuk menghasilkan kualitas lulusan Perguruan Tinggi yang kompeten, salah satunya dipengaruhi oleh keberhasilan dalam proses pembelajaran. Keterampilan berpikir merupakan keterampilan dalam 
menggabungkan sikap-sikap, pengetahuan, dan keterampilan-keterampilan yang memungkinkan seseorang untuk dapat membentuk lingkungannya agar lebih efektif. Keterampilan berpikir dapat dibedakan menjadi berpikir kritis dan berpikir kreatif (Putri Anjarsari, 2014). Banyaknya konsep yang abstrak dalam pembelajaran matematika mengakibatkan mahasiswa beranggapan matematika itu sulit. Mahasiswa baru mampu mempelajari dan menghafal fakta, konsep, prinsip, hukum, teori dan gagasan inovatif lainnya pada tingkat ingatan, mereka belum dapat menggunakan dan menerapkannya secara efektif dalam pemecahan masalah sehari-hari yang kontekstual. Matematika merupakan Mata Kuliah yang dapat menumbuhkan cara berpikir logis, sistematis, kritis dan rasional. Untuk menumbuhkan dan mengembangkan kemampuan mahasiswanya.

Hasil observasi proses belajar mengajar yang dilakukan di Program Studi DIII Teknik Komputer Politeknik Harapan Bersama sekarang ini masih menggunakan metode konvensional dalam penyampaian pembelajarannya. Metode pembelajaran konvensional meliputi berbagai metode yang berpusat pada dosen bidang studi. Mahasiswa kurang dilatih berfikir kritis untuk menyelesaikan soal dengan penyelesaian sendiri. Mahasiswa hanya mampu mnyelesaikan soal yang serupa yang dicontohkan oleh dosen sehingga jika diberikan pengembangan soal lain mahasiswa mengalami kesulitan. Kemampuan ini dapat dikembangkan melalui pembelajaran dimana masalah dihadirkan di kelas dan mahasiswa diminta untuk menyelesaikannya dengan segala pengetahuan dan keterampilan yang mereka miliki. Pembelajaran bukan lagi sebagai "transfer of knowledge", tetapi mengembangkan potensi mahasiswa secara sadar melalui kemampuan yang lebih dinamis dan aplikatif(Pendidikan and Kusuma 2017). Seharusnya, pembelajaran di dalam kelas menjadikan mahasiswa sebagai pusat pembelajaran sehingga mahasiswa dapat aktif dalam membangun pengetahuannya sendiri. Hal ini sejalan dengan pendapat Bruner (Trianto, 2009) bahwa belajar adalah proses aktif dimana mahasiswa membangun pengetahuan berdasarkan pengalaman yang sudah dimilikinya. Maka diperlukan suatu model pembelajaran yang berpusat pada mahasiswa dan dapat memberikan pengalaman mahasiswa dalam menyelesaikan soal matematika. Satu di antara model pembelajaran yang dapat diterapkan adalah model pembelajaran problem based learning.

Menurut Suci (2008), model pembelajaran problem based learning memiliki karakteristik yang membedakannya dengan model pembelajaran yang lainnya yaitu pembelajaran yang bersifat student centered atau berpusat pada siswa. Savery \& Duffy dalam Kuo Shu Huang (2012) menyatakan "problem-based learning as a 
curriculum design that identified students not as passive recipients of knowledge but as problem solvers who could develop disciplinary knowledge" artinya pembelajaran berbasis masalah sebagai desain kurikulum yang diidentifikasi peserta didik tidak sebagai penerima pasif pengetahuan tetapi sebagai pemecah masalah yang bisa mengembangkan pengetahuan. Menurut Arends (2008) bahwa Problem Based Learning dapat menjadikan peserta didik mandiri dalam menyelesaikan soal yang diberikan. Selanjutnya Trianto (2009) berpendapat bahwa usaha mencari penyelesaian secara mandiri akan memberikan pengalaman untuk menyelesaikan soal yang diberikan. Oleh karena itu, problem based learning dapat memberikan pengalaman dalam penyelesaian soal sehingga hasil belajar peserta didik meningkat. Sudarman (2007) menyatakan bahwa langkah pembelajaran problem based learning yaitu konsep dasar, pendefinisian masalah, belajar mandiri, pertukaran informasi atau belajar kelompok, dan penilaian. Melatih mahasiswa untuk terampil berfikir kritis melalui beberapa tahapantahapan sehingga dibutukan pendekatan pembelajaran yang sesuai yaitu dengan pendekatan saintifik. Dalam Standar Proses pembelajaran dengan pendekatan saintifik meliputi langkah-langkah: mengamati, menanya, mencoba, mengasosiasi, mengomunikasikan, dan mencipta. Pendekatan scientific dianggap menjadikan pembelajaran lebih aktif dan tidak membosankan, siswa dapat mengonstruksi pengetahuan dan keterampilannya melalui fakta-fakta yang ditemukan dalam penyelidikan di lapangan guna pembelajaran. Selain itu, dengan pembelajaran berbasis pendekatan scientific ini, siswa didorong lebih mampu dalam mengobservasi, bertanya, bernalar, dan mengomunikasikan atau mempresentasikan hal-hal yang dipelajari dari fenomena alam ataupun pengalaman langsung (Kemendikbud, 2013: 203,212).

Menurut Enis $(1991,1996)$ kriteria atau elemen dasar yang harus dimiliki oleh pemikir kritis dalam memecahkan masalah adalah disingkat dengan Focus, Reason, Inference, Situation, Clarity, and Overview yang dapat disingkat dengan istilah FRISCO(Cahyono 2017). Indikator keterampilan berfikir kitis pada penelitian ini yaitu ) Mampu menganalisis argument, 2) mampu mengevaluasi informasi, 3) mampu mensintesis bukti, dan 4) mampu menarik kesimpulan(Safrida et al. 2018).

\section{B. METODE PENELITIAN}

Prosedur penelitian ini terdiri dari 3 tahap yaitu tahap persiapan penelitian dan tahap pelaksanaan penelitian dan tahapan pasca penelitian. Tahap Persiapan Penelitian meliputi(Kusuma et al. 2018): a) Melakukan observasi awal untuk analisis penyebab masalah, b) pemilihan strategi dan metode pembelajaran yang akan diujikan, c) penyusunan rencana pelaksanaan pembelajaran (RPP), lembar observasi aktifitas pembelajaran mahasiswa, d) 
menentukan indikator penelitian dengan Keefektifan pembelajaran tersebut ditentukan dengan indikator, yaitu: 1) kemampuan Keterampilan berfikir kritismahasiswa yang diberikan perlakuan Problem Based Learning dengan Pendekatan Saintifik mencapai ketuntasan belajar minimal baik (B) individu maupun klasikal, 2) kemampuan keterampilan berfikir kritis mahasiswa diberikan perlakuan Problem Based Learning dengan Pendekatan Saintifik lebih baik dari pembelajaran ekspositori, 3) adanya peningkatan kemampuan keterampilan berfikir kritis mahasiswa yang diberikan perlakuan Problem Based Learning dengan Pendekatan Saintifik lebih baik dari pembelajaran ekspositori. e) Melakukan uji normalitas dan homogenitas pada dua sampel kelas. f) Memilih satu sampel kelas secara acak (random) sebagai kelas eksperimen yang diberikan treatmen Problem Based Learning dengan Pendekatan Saintifik,, g) Melaksanakan uji instrumen (soal) penilaian, dengan mengujicobakan instrtumen di kelas lain (kelas diluar sampel). h) Setelah diuji cobakan, maka hasil dari uji coba dianalisis data soal tentang validitas, reliabilitas, tingkat kesukaran soal dan daya beda soal. Tahap pelaksanaan penelitian terdiri dari:1) Pengolahan data penelitian dimana data yang diolah diambil dari 2 kelas, dimana 1(satu) kelas kontrol dan 1 (satu) kelas eksperimen yang disesuaikan dengan indikator penelitian yaitu a) uji ketuntasan rata-rata, b) Uji banding 2 sampel, c) uji proporsi dan d) uji peningkatan N-Gain. 2) Analisis Data Penelitian, setelah pengolahan data selesai dilanjutkan dengan analisis hasil penelitian untuk memperoleh interpretasi kesimpulan hasil dari masing-masing data penelitian yang sudah diolah.Tahap Setelah Penelitian yaitu 1) melakukan Evaluasi kegiatan, dimana dilakukan untuk melihat sejauh mana keberhasilan penelitian dengan memnuhi semua indikator penelitian yang sudah ditentukan sehingga metode pembelajaran yang ditawarkan pada kelas eksperimen (Problem Based Learning dengan Pendekatan Saintifik) lebih baik dengan pembelajaran yang sudah ada pada kelas kontrol (Metode Ekspositori).2) Publikasi Penelitian, Menyusun laporan penelitian yang dilanjutkan menyusun jurnal yang akan dipublikasi baik jurnal nasional terakreditasi mapun tidak terakreditasi. Jenis pada penenlitian ini yaitu penelitian kuantitatif dengan teknik pengumpulan data menggunakan tes, observasi, wawancara dan dokumentasi. analisis data efektifitas keberhasilan penelitian dengan menggunakan SPSS dengan melakukan uji normalitas, uji homogenitas, uji ketuntasan rata-rata, uji proporsi, uji banding dan uji peningkatan $\mathrm{N}$ Gain

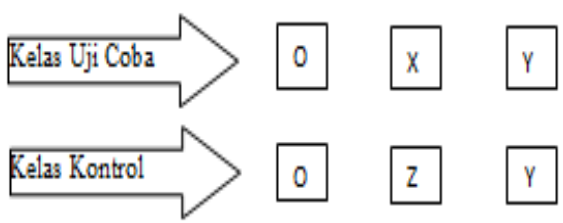

Gambar 1. Desain Penelitian Keterangan: 
$\mathrm{O}$ : dua kelas yang dipilih secara random, $\mathrm{X}$ : perlakuan dengan Problem Based Learning dengan Pendekatan Saintifik, Z : perlakuan dengan pembelajaran ekspositori, $\mathrm{Y}$ : tes kemampuan keterampilan berfikir kritis mahasiswa .

Pendekatan saintifik dimaksudkan untuk memberi pemahaman kepada peserta didik untuk mengetahui, memahami, mempraktikkan apa yang sedang dipelajari secara ilmiah. Oleh karena itu, dalam proses pembelajaran diajarkan agar peserta didik pencari tahu dari berbagai sumber melalui mengamati, menanya, mencoba, mengolah, menyajikan, menyimpulkan, dan mencipta untuk semua mata pelajaran) (Sudarwan, 2013).

\section{HASIL DAN PEMBAHASAN}

Hasil validasi perangkat pembelajaran digunakan untuk menentukan apakah perangkat pembelajaran dapat dipakai atau tidak dalam pembelajaran. Validasi perangkat pembelajaran dilakukan oleh dua ahli dan tiga teman sejawat Rekapitulasi hasil validasi ahli terhadap perangkat pembelajaran dapat dilihat pada Tabel 1 berikut.

\begin{tabular}{cccc}
\multicolumn{4}{c}{ Tabel 1 Rekapitulasi Hasil Validasi Perangkat } \\
\hline Perangkat & $\begin{array}{c}\text { Rata- } \\
\text { rata }\end{array}$ & Keterangan & Kriteria \\
\hline RPS & 4.00 & Valid & Baik \\
RPP & 4.10 & Valid & Baik \\
Buku Ajar & 4.03 & Valid & Baik \\
LKM & 4.01 & Valid & Baik \\
TKKBKM & 4.00 & Valid & Baik \\
\hline
\end{tabular}

Pengolahan data sekunder nilai UAS Mahasiswa. Penentuan kelas eksperimen dan dilakukan dalam menentukan kelas kelas kontrol berdasarkan hasil olah data eksperimen dan kelas kontrol. Jumlah SPSS melalui uji prasyarat yaitu uji mahasiswa kelas D yang hadir terdiri dari 32 normalitas dan Uji Homogenitas. Adapun mahasiswa dan kelas $\mathrm{F}$ berjumlah 32 hasil olah datanya sebagai berikut.

Tabel 2 Hasil Uji Normalitas Data Awal

Tests of Normality

\begin{tabular}{|c|c|c|c|c|c|c|}
\hline \multirow{2}{*}{} & \multicolumn{3}{|c|}{ Kolmogorov-Smirnov $^{\mathrm{a}}$} & \multicolumn{3}{c|}{ Shapiro-Wilk } \\
\cline { 2 - 7 } & Statistic & $\mathrm{df}$ & Sig. & Statistic & $\mathrm{df}$ & Sig. \\
\hline $\begin{array}{c}\text { NILA } \\
\text { I }\end{array}$ & .082 & 64 & $.200^{*}$ & .975 & 64 & .224 \\
\hline
\end{tabular}

*. This is a lower bound of the true significance.

a. Lilliefors Significance Correction

Berdasarkan Tabel 2 jika nilai signifikan pada

kolom Kolmogrov Smirnov > 5\% maka $\mathrm{H}_{0}$ diterima yaitu 0.200 atau $20 \%>5 \%$ dan $\mathrm{H}_{1}$ ditolak. Hal ini berarti data kelas sampel berdistribusi normal. 
Tabel 3 Hasil Uji Homogenitas Data UAS Ganjil TA 2018/2019

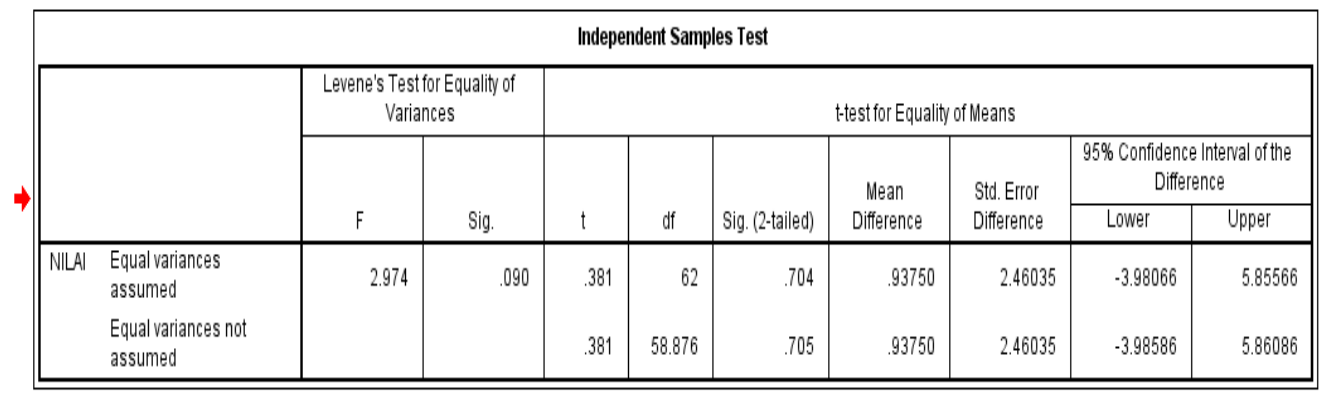

Dari Tabel 3 Hasil uji homogenitas diperoleh nilai sig adalah 0,09 atau 9\%. Nilai signifikan tersebut lebih besar dari $5 \% \quad \mathrm{H}_{0}$ diterima. Maka dapat disimpulkan bahwa mahasiswa di kelas D dan F mempunyai varian yang sama atau kedua kelas mempunyai kemampuan yang homogen/sama. Setelah dilakukan pengujian normalitas dan homogenitas kelas D dan F maka peneliti mengambil secara acak bahwa kelas $\mathrm{F}$ akan dijadikan sebagai kelas eksperimen dan kelas D dijadikan sebagai kelas kontrol.

Tabel 4 Hasil Ketuntasan KKM

One-Sample Test

\begin{tabular}{|c|c|c|c|c|c|c|}
\hline & \multicolumn{6}{|c|}{ Test Value $=68$} \\
\hline & \multirow[b]{2}{*}{$\mathrm{t}$} & \multirow[b]{2}{*}{$\mathrm{df}$} & \multirow{2}{*}{$\begin{array}{l}\text { Sig. }(2- \\
\text { tailed) }\end{array}$} & \multirow{2}{*}{$\begin{array}{c}\text { Mean } \\
\text { Difference }\end{array}$} & \multicolumn{2}{|c|}{$\begin{array}{l}95 \% \text { Confidence Interval of } \\
\text { the Difference }\end{array}$} \\
\hline & & & & & Lower & Upper \\
\hline $\begin{array}{l}\text { NILAI_POSTE } \\
\text { ST }\end{array}$ & 8.841 & 63 & .000 & 9.84375 & 7.6188 & 12.0687 \\
\hline
\end{tabular}

Berdasarkan Tabel 4 jika nilai signifikan pada kolom sig (2-tailed) > 5\% maka $\mathrm{H}_{0}$ diterima yaitu 0.000 atau $0 \%<5 \%$ dan H0 ditolak berarti $\mathrm{H}_{1}$ diterima. Hal ini artinya rata-rata ketuntasan lebih dari sama dengan $\mathrm{KKM}=$ 68.

Ketuntasan belajar secara klasikal dalam penelitian ini apabila rata-rata TKKBKM dengan pembelajaran PBL dengan pendekatan saintifik lebih dari 68 dan mahasiswa yang mendapatkan nilai di atas 68 sebanyak $75 \%$. Ketuntasan belajar yang dimaksudkan ketuntasan terhadap komunikasi matematik. Uji ketuntasan diambil dari nilai yang diperoleh mahasiswa dari TKKBKM pada kelas yang menggunakan pembelajaran PBL dengan pendekatan saintifik pada akhir pembelajaran. Menguji apakah tiap mahasiswa tuntas dalam belajar maka dilakukan uji proporsi. Uji ini dilakukan untuk mengetahui apakah nilai TKKBKM mahasiswa minimal sama dengan KKM mencapai sekurang-kurangnya $75 \%$. Untuk mengetahuinya dilakukan uji $Z$. 
Karena perhitungan nilai $Z=2,04$ lebih besar dibandingkan $Z$ tabel yaitu 1,684 dengan derajat kepercayaan $5 \%$, maka tolak $\mathrm{H}_{0}$ dan terima $\mathrm{H}_{1}$. Artinya bahwa proporsi mahasiswa yang sudah mendapatkan > 68 sudah melampaui $75 \%$.

Tabel 5 Hasil Uji Banding

\begin{tabular}{|c|c|c|c|c|c|c|c|c|c|c|}
\hline \multicolumn{11}{|c|}{ Independent Samples Test } \\
\hline & & \multicolumn{2}{|c|}{$\begin{array}{c}\text { Levene's Test for Equality of } \\
\text { Variances }\end{array}$} & \multicolumn{7}{|c|}{ t-test for Equality of Means } \\
\hline & & \multirow[b]{2}{*}{ F } & \multirow[b]{2}{*}{ Sig. } & \multirow[b]{2}{*}{$t$} & \multirow[b]{2}{*}{$d f$} & \multirow[b]{2}{*}{ Sig. (2-tailed) } & \multirow{2}{*}{$\begin{array}{c}\text { Mean } \\
\text { Difference }\end{array}$} & \multirow{2}{*}{$\begin{array}{l}\text { Std. Error } \\
\text { Difference }\end{array}$} & \multicolumn{2}{|c|}{$\begin{array}{l}\text { 95\% Confidence Interval of the } \\
\text { Difference }\end{array}$} \\
\hline & & & & & & & & & Lower & Upper \\
\hline NILAI_POSTEST & $\begin{array}{l}\text { Equal variances } \\
\text { assumed }\end{array}$ & 1.867 & .177 & 1.473 & 62 & .146 & 3.25000 & 2.20644 & -1.16061 & 7.66061 \\
\hline & $\begin{array}{l}\text { Equal variances not } \\
\text { assumed }\end{array}$ & & & 1.473 & 60.568 & .146 & 3.25000 & 2.20644 & -1.16269 & 7.66269 \\
\hline
\end{tabular}

Berdasarkan Tabel 5 uji banding di atas bahwa nilai $t_{\text {tabel }}$ pada distribusi nilai $\mathrm{t}$ adalah $d k=32+32-2=62$ dengan taraf signifikansi $5 \%$ adalah 1,473 Kesimpulannya bahwa nilai $t_{\text {hitung }}>t_{\text {tabel }}$ atau $1,664>1,473 \mathrm{H}_{0}$ ditolak dan $\mathrm{H}_{1}$ diterima artinya bahwa kemampuan Keterampilan berfikir kritismahasiswa yang menggunakan pembelajaran PBL dengan pendekatan saintifik lebih besar daripada Keterampilan berfikir kritis mahasiswa yang diajarkan dengan pembelajaran ekspositori.

Uji peningkatan kemampuan Keterampilan berfikir kritisdilakukan dengan perhitungan nilai tes awal dan nilai tes akhir dalam kegiatan pembelajaran. Rumus yang digunakan ungtuk menghitung peningkatan kemampuan penalaran matematik adalah dengan menggunakan rumus nilai Normalitas Gain. Data dari hasil perhitungan nilai gain menunjukkan tingkat kenaikan nilai hasil penggunaan pembelajaran PBL dengan pendekatan saintifik sebesar 0,464 perolehan nilai gain tersebut menunjukkan kriteria sedang. Rekapitulasi Normalitas Gain seperti Tabel 6 berikut.

Tabel 6 Perhitungan N Gain

\begin{tabular}{ccccc}
\hline Nilai & Kelas & $\begin{array}{c}\text { Tes } \\
\text { awal }\end{array}$ & Tes akhir & $\begin{array}{c}\text { Nilai } \\
\text { Gain }\end{array}$ \\
\hline \multirow{2}{*}{ Rata-rata } & Eksperimen & $\mathbf{6 1 , 7 5}$ & $\mathbf{7 9 , 5}$ & $\mathbf{0 , 4 6 4}$ \\
\cline { 2 - 5 } & Kontrol & 61,45 & 76,2 & 0,382 \\
\hline
\end{tabular}

Selanjutnya pada peningkatan kemampuan Keterampilan berfikir kritismahasiswa dilakukan uji lanjut yaitu uji beda peningkatan. Dari Tabel hasil uji banding diperoleh nilai sig adalah 0,337 atau $33,7 \%$. Nilai signifikan tersebut lebih besar dari $5 \%$ $\mathrm{H}_{0}$ diterima. Maka dapat disimpulkan bahwa data peningkatan selisih TKKBKM mempunyai varian yang sama/homogeny.

Berdasarkan tabel uji banding diatas maka tolak $\mathrm{H}_{0}$ dan terima $\mathrm{H}_{1}$ artinya selisih peningkatan kemampuan Keterampilan berfikir kritis mahasiswa yang diberikan perlakuan pembelajaran $P B L$ dengan 
pendekatan saintifik lebih besar dari pembelajaran Ekspositori. Pembelajaran pada kelas ujicoba (eksperimen) dan kelas kontrol terdapat persamaan dan perbedaan. Persamaannya adalah bahwa peneliti bertindak sebagai dosen pada kedua kelas tersebut, sama-sama diberikan penelitian tes kemampuan keterampilan berfikir kritis, sedangkan perbedaannya terletak pada model pembelajaran yang digunakan saat pembelajaran. Pada kelas ujicoba mendapat perlakukan pembelajaran $P B L$ dengan pendekatan saintifik sedangkan kelas kontrol mendapatkan perlakuan pembelajaran ekspositori. Pada kelas ujicoba pengamatan terhadap keterlaksanaan RPP, pengisian lembar respon dosen, pengamatan aktivitas Keterampilan berfikir kritis diadakan pada pertemuan 1-5 dilakukan oleh observer yaitu teman sejawat, soal TKKBKM diisi oleh mahasiswa sendiri. Ujicoba terbatas TKKBKM dilakukan di kelas 2C hal ini dikarenakan untuk mendapatkan sampel yang cukup sehingga data yang diperolehpun diharapkan baik.

Berdasarkan pemaparan hal tersebut, dapat disimpulkan bahwa pembelajaran dengan menggunakan pendekatan saintifik adalah upaya dosen dalam membelajarkan siswa melalui proses pembelajaran yang bersifat ilmiah. Pembelajaran bukanlah suatu proses yang didominasi oleh dosen melainkan pembelajaran lebih menuntut kepada mahasiswa aktif untuk mengkonstruksi pengetahuannya sendiri melalui kegiatan mengamati, menanya, mengumpulkan informasi/mencoba, menalar/mengasosiasikan dan mengkomunikasikan(Angga et al. 2016).

Buku ajar yang dibuat oleh dosen terbukti memberikan peran yang efektif dan strategis dalam upaya mengelola pembelajaran di kelas. Dengan buku yang sudah disusun sesuai dengan alur pembelajaran yang direncanakan, pelaksanaan pembelajaran berjalan dengan lancar, sehingga mahasiswa dapat mengikuti pembelajaran dengan maksimal. Dalam perancangan dan penyusunan buku ajar dalam mengembangkan perangkat ini, senantiasa selalu diserelaraskan antara materi dan model yang digunakan dalam pembelajaran. Unsurunsur yang dijadikan dasar pembuatan buku ajar, yaitu: 1) kelengkapan materi pelajaran, 2) ketertarikan mahasiswa terhadap buku ajar, 3) pemberian tantangan soal untuk mengembangkan pengetahuan mahasiswa, 4) penberian contoh penyelesaian secara sistematis, 5) pemberian latihan uji kompetensi sebagai pemantapan akhir pembelajaran, 6) pemberian kunci jawaban sebagai bahan pengontrol jawaban, 7) pemberian gambar pendukung yang menarik mahasiswa, dan 8) penggunaan bahasa yang sederhana sehingga mudah dipahami.

Hasil yang nampak dalam ujicoba perangkat penggunaan LKM ternyata masih cukup antusias dalam kegiatan pembelajaran. Mahasiswa lebih aktif berdiskusi dengan kelompoknya, melatih mahasiswa mempertahankan pendapatnya kemudian 
melatih mahasiswa untuk menerima masukan dari kelompoknya. Akan tetapi pembelajaran dengan menggunakan LKM ada efek negatifnya yaitu mahasiswa cenderung malas untuk mendokumentasikan apa yang didiskusikan di dalam LKM, kemudian memerlukan cukup banyak waktu jika masalah yang didiskusikan belum menemui titik penyelesaian. Berpikir kritis wajib dimiliki oleh lulusan Program Sarjana. Hal tersebut tercantum pada Peraturan Menteri Pendidikan dan Kebudayaan Republik Indonesia Nomor 49 Tahun 2014 tentang Standar Nasional Pendidikan Tinggi Pasal 6 yang berbunyi bahwa lulusan Program Sarjana wajib memiliki keterampilan umum, yaitu mampu menerapkan pemikiran logis, kritis, sistematis, dan inovatif dalam konteks pengembangan atau implementasi ilmu pengetahuan dan teknologi yang memperhatikan dan menerapkan nilai humaniora yang sesuai dengan bidang keahliannya. Pemberian masalah disajikan dalam bentuk tugas tertulis. Tugas tertulis memuat pertanyaan-pertanyaan terkait wacana yang berisi isu lingkungan. Pertanyaan pertanyaan tersebut memuat elemen-elemen bernalar Paul \& Elder (1997) dan disusun berdasarkan sintak penyelesaian masalah Polya (1973). Elemen-elemen bernalar Paul \& Elder (1997) diterapkan dalam tugas tertulis dalam bentuk indikator kemampuan berpikir kritis(Mulia 2016). Jawaban mahasiswa kemudian dinilai berdasarkan standar intelektual bernalar Paul \& Elder (2010) dengan menggunakan metode skoring

Tabel 7 Rekapitulasi Indikator KKBKM

\begin{tabular}{|c|c|c|c|c|}
\hline \multirow[t]{2}{*}{ Soal } & \multicolumn{4}{|c|}{ Indikatator KKВKM } \\
\hline & Indikator 1 & Indikator 2 & Indikator 3 & Indikator 4 \\
\hline Rata-rata & 8.125 & 8.56 & 5.87 & 7.71 \\
\hline Rata total & & & 7.57 & \\
\hline
\end{tabular}

Dalam penelitian ini terdiri dari 4 menyusun pembuktian memperoleh 5,87 paling rendah dibandingkan ketiga indikator yang lainnya dan diperoleh rata-rata kemampuan Keterampilan berfikir kritis 7,57. Dari beberapa paparan di atas, maka dapat disimpulkan bahwa keterampilan berfikir kritis dengan indikator 1) Mampu menganalisis argument, 2) mampu mengevaluasi informasi, 3) mampu mensintesis bukti, dan 4) mampu menarik kesimpulan masih dalam nilai cukup, pertemuan utama dimana pertemuan pertama pemberian pengetahuan mengenai pembelajaran PBL dengan pendekatan saintifik, pemberian pretest kemampuan Keterampilan berfikir kritis mahasiswa, penyampaian materi dilakukan pada pertemuan ke 1 - 3 secara teori dan pertemuan 4 pemberian praktek menggunakan SPSS dengan diatur posisi mahasiswa berkelompok dimana terdiri dari 3 
- 5 mahasiswa. Pertemuan ke 6 pemberian posttest yang dilanjutkan dengan pemberian umpan balik dari penyelesaian mahasiswa. Di setiap pertemuan mahasiswa diberikan tugas sebagai syarat mengikuti perkuliahan selanjutnya. Tugas berisi soal multiple choise yang hasil penyelesaiannyaa lanagsung dapat diketahui oleh mahasiswa. Dibentuknya kelompok untuk berdiskusi sesuai dengan Within (1992) menyatakan kemampuan komunikasi menjadi penting ketika diskusi antar mahasiswa dilakukan, dimana mahasiswa diharapkan mampu menyatakan, menjelaskan, menggambarkan, mendengar, menanyakan dan bekerjasama sehingga dapat membawa mahasiswa pada pemahaman yang mendalam tentang matematika. Anak-anak yang diberikan kesempatan untuk bekerja dalam kelompok dalam mengumpulkan dan menyajikan data, mereka menunjukkan kemajuan baik di saat mereka saling mendengarkan ide yang satu dan yang lain, mendiskusikannya bersama kemudian menyusun kesimpulan yang menjadi pendapat kelompoknya. Ternyata mereka belajar sebagian besar dari berkomunikasi dan mengkontruksi sendiri pengetahuan mereka. Pembelajaran dengan pendekatan saintifik adalah proses pembelajaran yang dirancang sedemikian rupa agar peserta didik secara aktif mengonstruk konsep, hukum atau prinsip melalui tahapan-tahapan mengamati (untuk mengidentifikasi atau menemukan masalah), merumuskan masalah, mengajukan atau merumuskan hipotesis, mengumpulkan data dengan berbagai teknik, menganalisis data, menarik kesimpulan dan mengomunikasikan konsep, hukum atau prinsip yang "ditemukan". Pendekatan saintifik dimaksudkan untuk memberikan pemahaman kepada peserta didik dalam mengenal, memahami berbagai materi menggunakan pendekatan ilmiah, bahwa informasi bisa berasal dari mana saja, kapan saja, tidak bergantung pada informasi searah dari dosen. Oleh karena itu kondisi pembelajaran yang diharapkan tercipta diarahkan untuk mendorong peserta didik dalam mencari tahu dari berbagai sumber melalui observasi, dan bukan hanya diberi tahu.(Sufairoh 2016)

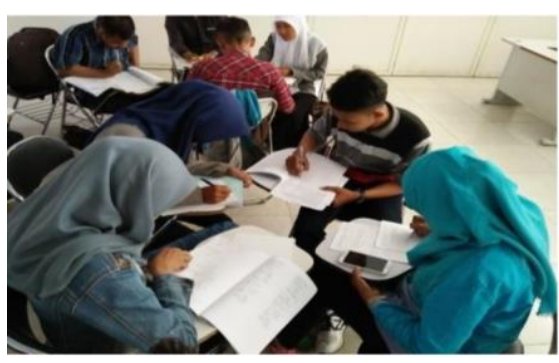

Gambar 2 Diskusi Kelompok di Ruang Kelas

Glazer (Mulyani, 2014:16) menyatakan bahwa berpikir kritis dalam matematika adalah keterampilan kognitif dan disposisi untuk menggabungkan pengetahuan, penalaran, serta strategi kognitif dalam membuat generalisasi, membuktikan, dan mengevaluasi situasi matematik yang tidak dikenal dengan cara reflektif(Erny, Haji, and Widada 2016).

Hasil penyelesaian mahasiswa pada posttest tiap-tiap mahasiswa berbeda-beda. Penyebab perbedaan prestasi belajar tersebut terdapat dalam diri mahasiswa dengan berbagai latar 
belakangnya. Banyak sekali faktor-faktor yang dapat mempengaruhi prestasi belajar seorang mahasiswa, baik yang berasal dari luar mahasiswa sehingga tidak jarang ditemui mahasiswa dalam suatu kelas dengan dosen yang sama, lingkungan yang sama, dan fasilitas yang sama namun hasil yang dicapai masing-masing mahasiswa berbeda. Adapun kutipan wawancara mengenai soal yang mahasiswa sulit menyelesaikan pada indicator mensintesis bukti sebagai berikut.

Dosen : "emm... nang, tadi bagaimana Posttestnya?"

RS-10 : "yaa, begitulah pak...."

Dosen : "begitu, bagaimana...??? Oya tadi bapak lihat jawaban yang nomor 3 kamu, kamu ambil misalkan $\mathrm{p}=1$ dan $\mathrm{q}=2$ ? Kenapa tidak q = 1 ?"

RS-10 : "ohh ya pak, yang membuktikan sifat mean itu. karena untuk pengambilan $\mathrm{p}=$ 1, pasti tetap nampak perubahan nilai rataratanya, tetapi untuk q guru tidak mengambil 1 karena anggapan guru nilai apapun jika dikalikan 1 tidak mengalami perubahan sehingga sulit menjawab pembuktian pertanyaan poin b). maka dari itu selain mengambil $\mathrm{q}=2$ nilai perhitungan tidak terlalu banyak. "

Dosen : "oohhhh,,, begitu.."

RS-10 :"pak, jika misalkan seperti tadi sifat mean berlaku untuk penjumlahan dan perkalian berarti bisa berlaku juga untuk operasi selisih dan pembagian"

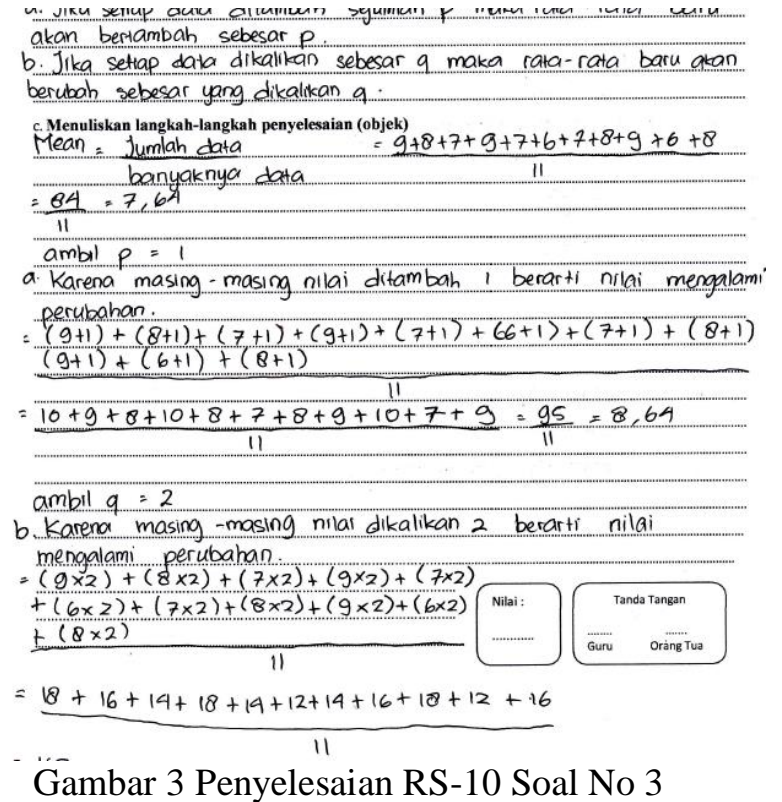

Pada pengambilan kesimpulan pada tahap skema bahwa dijelaskan nilai rata-rata sebelumnya 7,64 jika setiap data ditambah 1 maka nilai rata-ratanya bertambah menjadi 8,64 sesuai dengan penambahannya begitupun sebaliknya jika setiap data masingmasing dikalikan 2 kemudian menjadi 17,28 bertambah sejumlah nilai yang dikalikan. Kemudian RS-10 berusaha menghubungkan sifat mean dengan operasi selisih dan pembagian sesuai dengan wawancara di atas.

\section{PENUTUP}

Berdasarkan analisis dan pembahasan pada bab sebelumnya maka simpulan dalam penelitian ini pembelajaran menggunakan model pembelajaran PBL dengan pendekatan saintifik efektif, hal ini dapat dinyatakan sebagai berikut. a) Mahasiswa di kelas yang menggunakan model pembelajaran PBL dengan pendekatan saintifik pada materi statistika mencapai tuntas $75 \%$. b) Rata-rata ketuntasan melebihi nilai KKM sebesar 68 . Adapun 3 mahasiswa di kelas eksperiman dan 
7 mahasiswa di kelas kontrol yang tidak lulus,

c) Kemampuan Keterampilan berfikir kritismahasiswa pembelajaran PBL dengan pendekatan saintifik lebih baik daripada pembelajaran ekspositori. d) Adanya peningkatan kemampuan Keterampilan berfikir kritis mahasiswa pembelajaran PBL dengan pendekatan saintifik sebesar 0.464 kategori sedang. e) Adanya peningkatan selisih selisih peningkatan kemampuan Keterampilan berfikir kritismahasiswa yang diberikan perlakuan pembelajaran $P B L$ dengan pendekatan saintifik lebih besar dari pembelajaran Ekspositori

Berdasarkan hasil penelitian pengembangan pembelajaran PBL dengan pendekatan saintifik materi statistika untuk meningkatkan kemampuan berfikir kritis, peneliti memberikan saran sebagai berikut : Proses penyelesaian yang berkaitan dengan proses kemampuan berfikir kritis mahasiswa, dosen diharapkan memperhatikan bagaimana mahasiswa menyelesaikan sehingga dosen mengetahui alur pola pikir yang dituju mahasiswa, dari hal ini dosendapat memberikan tindaklanjut untuk mengarahkan pola pikir mahasiswa jika terdapat kekeliruan. Dengan melihat jawaban tertulis mencerminkan kemampuan asli dari mahasiswa.

\section{E. REFERENSI}

Angga, I Pt et al. 2016. "PENGUASAAN KOMPETENSI PENGETAHUAN IPS."

Cahyono, Budi. 2017. "Analisis Ketrampilan Berfikir Kritis Dalam.” Aksioma 8(1): 50-64.
Erny, Erny, Saleh Haji, and Wahyu Widada. 2016. "Pengaruh Pendekatan Saintifik Pada Pembelajaran Matematika Terhadap Kemampuan Pemecahan Masalah Dan Kemampuan Berpikir Tingkat Tinggi Siswa Kelas X Ipa Sma Negeri 1 Kepahiang.” Jurnal Pendidikan Matematika Raflesia 2(1).

Kusuma, Adi Candra et al. 2018. "Efektifitas Pembelajaran Guided Teaching Dengan E-Learning Untuk Meningkatkan Kemampuan Komunikasi Matematik Mahasiswa PENDAHULUAN Dalam Upaya Meningkatkan Mutu Pendidikan, Kegiatan Belajar Berperan Sangat Penting , Dimana KBM Di Perguruan Tinggi Terjadi." 1(3): 315-27.

Mulia, M A. 2016. "Keefektifan Model PBL Berpendekatan Realistik Saintifik Untuk Meningkatkan Kemampuan Berpikir Kritis Siswa Dalam Pembelajaran Matematika." (2013): 50-61.

Pendidikan, Jurnal, and Adi Candra Kusuma. 2017. "Cakrawala." (2): 1-8.

Safrida, Lela Nur, Reza Ambarwati, Robiatul Adawiyah, and Ermita Rizki Albirri. 2018. "Analisis Kemampuan Berpikir Kritis Mahasiswa Program Studi Pendidikan Matematika." EDU-MAT Jurnal Pendidikan Matematika 6(1): $10-16$.

Sufairoh. 2016. "Pendekatan Saintifik \& Model Pembelajaran K-13." Jurnal Pendidikan Profesional 5(3): 117-25. 
